\title{
Archaeological Monitoring of the Caldwell County Courthouse Rehabilitation, Lockhart, Texas
}

Steve A. Tomka

Raba Kistner

Anne A. Fox

Follow this and additional works at: https://scholarworks.sfasu.edu/ita

Part of the American Material Culture Commons, Archaeological Anthropology Commons, Environmental Studies Commons, Other American Studies Commons, Other Arts and Humanities Commons, Other History of Art, Architecture, and Archaeology Commons, and the United States History Commons

Tell us how this article helped you.

This Article is brought to you for free and open access by the Center for Regional Heritage Research at SFA ScholarWorks. It has been accepted for inclusion in Index of Texas Archaeology: Open Access Gray Literature from the Lone Star State by an authorized editor of SFA ScholarWorks. For more information, please contact cdsscholarworks@sfasu.edu. 


\section{Archaeological Monitoring of the Caldwell County Courthouse Rehabilitation, Lockhart, Texas}

\section{Creative Commons License}

\section{(c) (1) (8)}

This work is licensed under a Creative Commons Attribution-NonCommercial 4.0 International License 


\title{
Archaeological Monitoring of the Caldwell County Courthouse Rehabilitation, Lockhart, Texas
}

\author{
by \\ Steve A. Tomka \\ and \\ Anne A. Fox
}

Robert J. Hard

Principal Investigator

Texas Antiquities Permit No. 2117

Ccopyright 2000

Center for Archaeological Research

The University of Texas at San Antonio

Archaeological Survey Report, No. 306 
The following information is provided in accordance with the General Rules of Practice and Procedure, Chapter 41.11 (Investigative Reports), Texas Antiquities Committee:

1. Type of investigation: Monitoring

2. Project name: Caldwell County Courthouse

3. County: Caldwell

4. Principal investigator: Robert J. Hard

5. Name and location of sponsoring agency: American Restoration, New Braunfels, Texas 78130

6. Texas Antiquities Permit No.: 2117

7. Published by the Center for Archaeological Research, The University of Texas at San Antonio, 6900 N. Loop 1604 W., San Antonio, Texas 78249-0658, 2000

A list of publications offered by the Center for Archaeological Research is available. Call (210) 458-4378; write to the Center for Archaeological Research, The University of Texas at San Antonio, 6900 N. Loop 1604 W., San Antonio, Texas 78249-0658; e-mail to car@lonestar.utsa.edu; or visit CAR's web site at http://csbs3.utsa.edu/car. 


\begin{abstract}
In February 1999, the Center for Archaeological Research (CAR) of The University of Texas at San Antonio (UTSA) entered into a contract with American Restoration of New Braunfels, Texas, to monitor utility trenches being excavated on the grounds of the Caldwell County Courthouse in Lockhart, Texas, under Texas Antiquities Permit No. 2117. The utilities were installed in connection with the exterior rehabilitation being conducted by the firm of Ford, Powell, and Carson, Architects. Five visits to the project between February and October of 1999 involved monitoring of mechanical trench excavations, selective screening of trenching backdirt, and surface collections. Monitoring of excavations and the inspection of trench profiles and contents have identified substantial disturbances on the courthouse grounds. These disturbances include utility line trenching associated with previous installations of water, sewer and electric lines, and grade modifications and introduced fill associated with landscaping. Selective screening and surface collections yielded artifacts relating to the construction and use of the three successive courthouses that have existed on the site. However, these artifacts derive from highly disturbed contexts and lack associational integrity. No traces of the foundations of the two previous courthouses were encountered during the trenching.
\end{abstract}




\section{Contents}

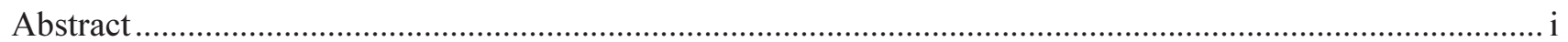

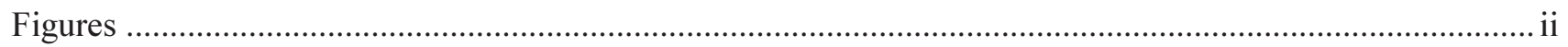

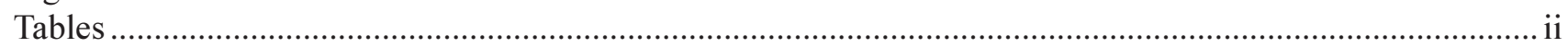

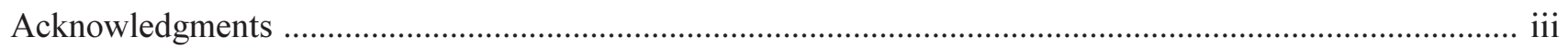

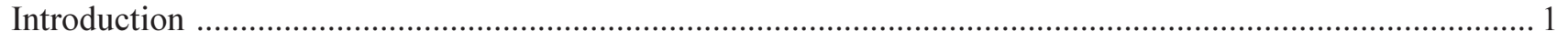

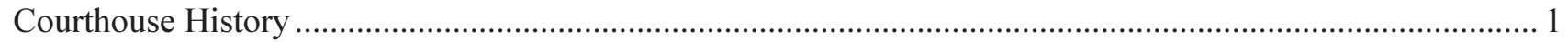

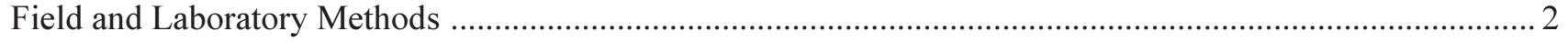

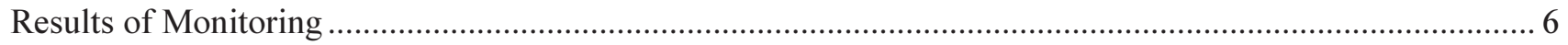

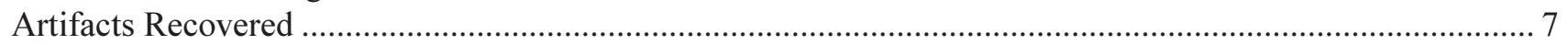

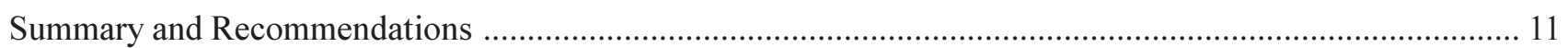

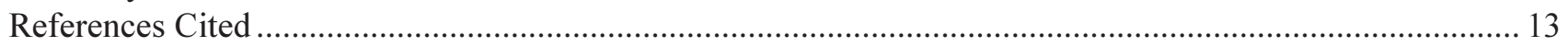

\section{Figures}

Figure 1. Location of Caldwell County Courthouse in Lockhart, Texas. ..................................................... 1

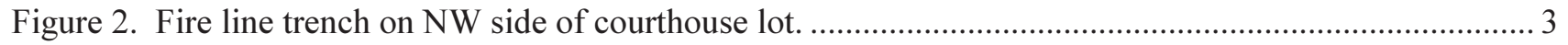

Figure 3. Electric line in 2-inch and 4-inch PVC conduit in Trench F. ..................................................... 4

Figure 4. Map of trenching associated with exterior rehabilitation of the courthouse. .................................. 5

Figure 5. Superimposed construction layers and underlying disturbed zones in Trench F. ............................ 6

Figure 6. Close-up of fire line trench showing level of disturbance into underlying caliche. ......................... 7

Figure 7. Caldwell County Courthouse on Courthouse Dedication Day, April 2000................................ 12

\section{Tables}

Table 1. Artifacts recovered from the monitoring of Caldwell County Courthouse rehabilitation activities. ... 8 


\section{Acknowledgments}

The authors would like to thank Dr. Robert Hard (Director of the Center for Archaeological Research) who served as Principal Investigator. We would also like to thank Ms. Katherine Fontenot of American Restoration, and Jeff Fetzer who served as the architect in charge of the restoration project from Ford, Powell, and Carson Architects, for their assistance in making this project possible. Finally, the project could not have been completed without the assistance of Mr. McRay Robbins, the job foreman, and Mr. J. T. Bertrand, electrician in charge of laying out, and -in some cases- excavating the trenches during the early stages of the project. Similarly, thanks are owed to Rick Robinson for his assistance in washing and cataloging the collection of artifacts recovered during the project. The technical support of editor Maryanne King is greatly appreciated. Our thanks

are also extended to Mr. Mike Annas, Annas Photography, of Lockhart, Texas for permitting us to use his recent photographs of the restored Caldwell County Courthouse. 



\section{Introduction}

In February 1999, the Center for Archaeological Research (CAR) of The University of Texas at San Antonio (UTSA) entered into a contract with American Restoration of New Braunfels, Texas, to monitor the excavation of utility trenches located on the grounds of the Caldwell County Courthouse in Lockhart, Texas
(Figure 1). The utilities were installed in connection with the exterior rehabilitation being conducted by the firm of Ford, Powell, and Carson, Architects. The archaeological monitoring at this particular site was required due to the fact that the courthouse is listed on the National Register of Historic Places. Therefore, the goal of the monitoring was to assure that the trench-

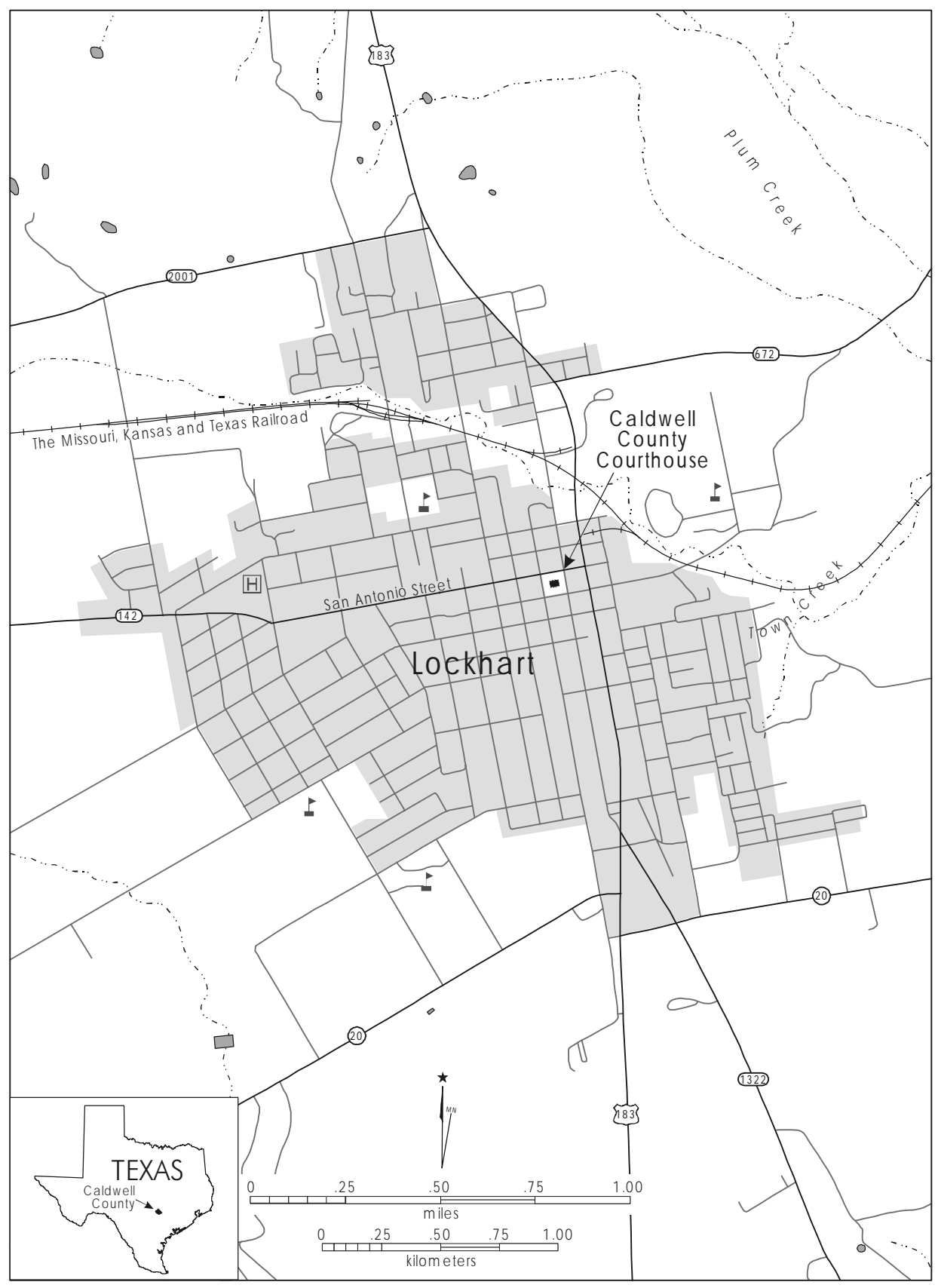

Figure 1. Location of Caldwell County Courthouse in Lockhart, Texas. 
ing activities would not impact intact cultural deposits, such as features and foundations.

Five visits to the project between February and October of 1999 involved the monitoring of mechanical trench excavations, and the selective screening of trenching backdirt and surface collections from the vicinity of the four corners of the courthouse building. These activities retrieved artifacts relating to the construction and use of the three successive courthouses that have existed on the site. No trace of the foundations of the two previous courthouses were encountered during the trenching.

Serving, as principal investigator was C. Britt Bousman until December 10, 1999 at which time Robert J. Hard became principal investigator. The project archaeologist was Steve Tomka, who was assisted by Rick Robinson. Texas Antiquities Permit No. 2117 was issued for the project.

\section{Courthouse History}

Organized on March 6, 1848, Caldwell County was named for Mathew Caldwell, one of the signers of the Texas Declaration of Independence. The new town of Lockhart became the county seat, and a courthouse was built on the town square in 1849 (Brice 1986:23).

By 1856 , the town was planning a new courthouse, which was completed in 1858 (Kelsey and Dyal 1993:58). The second courthouse constructed was a two-story masonry building built in the Greek Revival style, with a hipped roof covered with standing seam metal. It had 9-over-9 wood sash double hung windows (Volz and Associates 1992:3).

By 1890 , discussion was beginning on the need for a new, larger courthouse, but the projected cost was a major stumbling block. However, in 1893 the Commissioners Court accepted the plans and specifications of the firm of Martin, Byrne, and Johnston to build a new courthouse for $\$ 54,350$ which was to be completed in nine months (Brice 1986:23-24). The Lockhart Masonic Lodge \#690 laid the cornerstone for this third and present courthouse with much ceremony, and the building was formally received on March 19, 1894 (Brice 1986:24).
The new courthouse was a three-story masonry building capped by a mansard roof with a central clock tower. Around the perimeter was a multitude of mansard-derived roof forms. The roofs were covered with black slate. During the following 100 years various limited exterior and interior alterations were made as required by the changing uses of the county staff (Brice 1986:24; Volz and Associates 1992).

In 1998 the building began a complete restoration under the direction of the architectural firm of Ford, Powell, and Carson, Architects of San Antonio.

\section{Field and Laboratory Methods}

Steve A. Tomka made a total of five visits to the Caldwell County Courthouse between February and October, 1999. The purpose of these visits was to monitor the mechanical excavation of various trenches associated with the installation of water, sewage, and drain lines, and main and branch circuits for electric lines.

The first of the visits occurred on February 2, 1999. During this visit, Tomka met with Katherine Fontenot, project manager, of American Restoration and Jeff Fetzer, architect in charge of the restoration project, of Ford, Powell, and Carson, Architects. The discussions included the scope of the archaeological monitoring and the nature and general aspects of the excavation efforts associated with the installation of the various plumbing and electric lines.

In general, water, sewage, and drain lines required the excavation of 12-16 inch wide and 36-inch deep trenches (Figure 2). The installation of electric lines, encased in 1", 2" and 4" (under sidewalks) diameter PVC conduit, required the excavation of 6-inch wide and 18-24 inch deep trenches (Figure 3).

Trenches associated with the installation of main and branch electric circuits were excavated along the entire perimeter of the courthouse (Figure 4). The installation of water lines also required trenching around all but the northeast front of the building. A single sewage line was installed in a trench which extended from the southwest half of the building to the sewer main next to Market Street on the south side of the 
Figure 2. Fire line trench on NW side of courthouse lot.

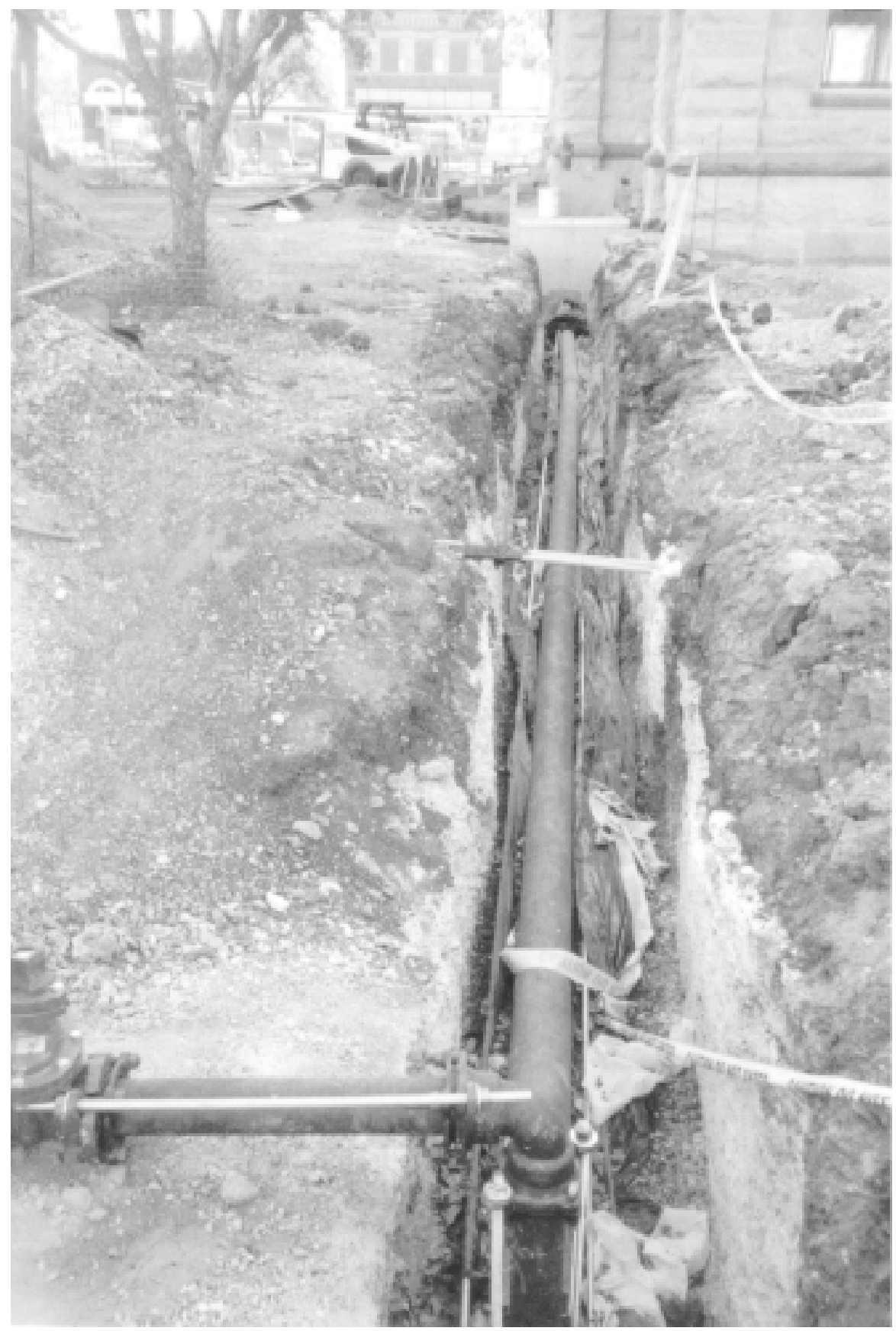

courthouse. Relatively short trenches were dug on the west and east sides of the building to accommodate site drain lines running perpendicular to Main and Commerce Streets, respectively.

Eight trenches excavated to receive electric lines were monitored (Trenches A-H). Monitoring in these cases consisted of observing the digging of the trenches, examining the profiles of the trenches, and screening approximately 15 gallons of backdirt from selected portions along the trenches. In addition, the excavation of eight light pedestal holes was also monitored on the four corners of the courthouse property. Light pedestal holes measured 24-inches in diameter and 
Figure 3. Electric line in 2-inch and 4-inch PVC conduit in Trench F.

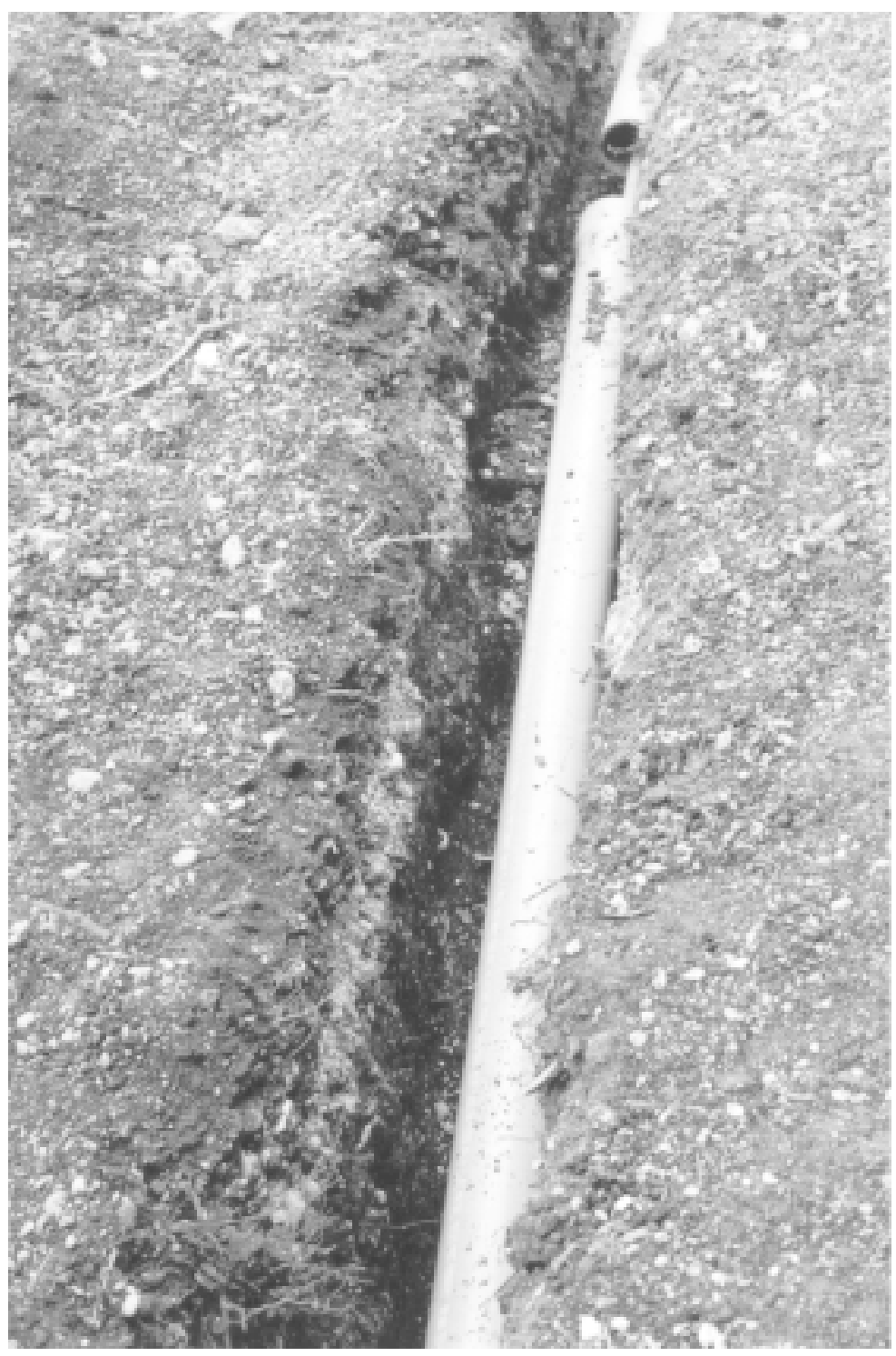

were dug to a depth of 24-inches below surface. Two additional trenches, associated with the installation of water lines were also monitored. They consisted of the main east-west running line located on the south side of the courthouse, and the main north-south running line located on the east-side of the courthouse. The excavation and installation of a water line serving fire extinguishing needs (e.g., fire line) adjacent to the northwest corner of the courthouse, was also monitored. In addition to these efforts, surface collections of artifacts were made at several locations including; adjacent the east entryway, and between the building and the sidewalk adjacent the four corners of the building. These areas appeared less disturbed by current construction activities and it was hoped that they would provide a sample of surface artifacts to contrast with the artifacts obtained from the trench backdirt piles.

During the first visit to the project area, Tomka consulted with Mr. McRay Robbins, the job foreman, and Mr. J. T. Bertrand, electrician in charge of laying out and in some cases excavating the trenches. The general procedure established during the first site visit was followed for each subsequent site visit-consultation, followed by the monitoring of the trench excavations, the detailed inspection of trench profiles, drawing and photographing selected sections of the 
San Antonio Street

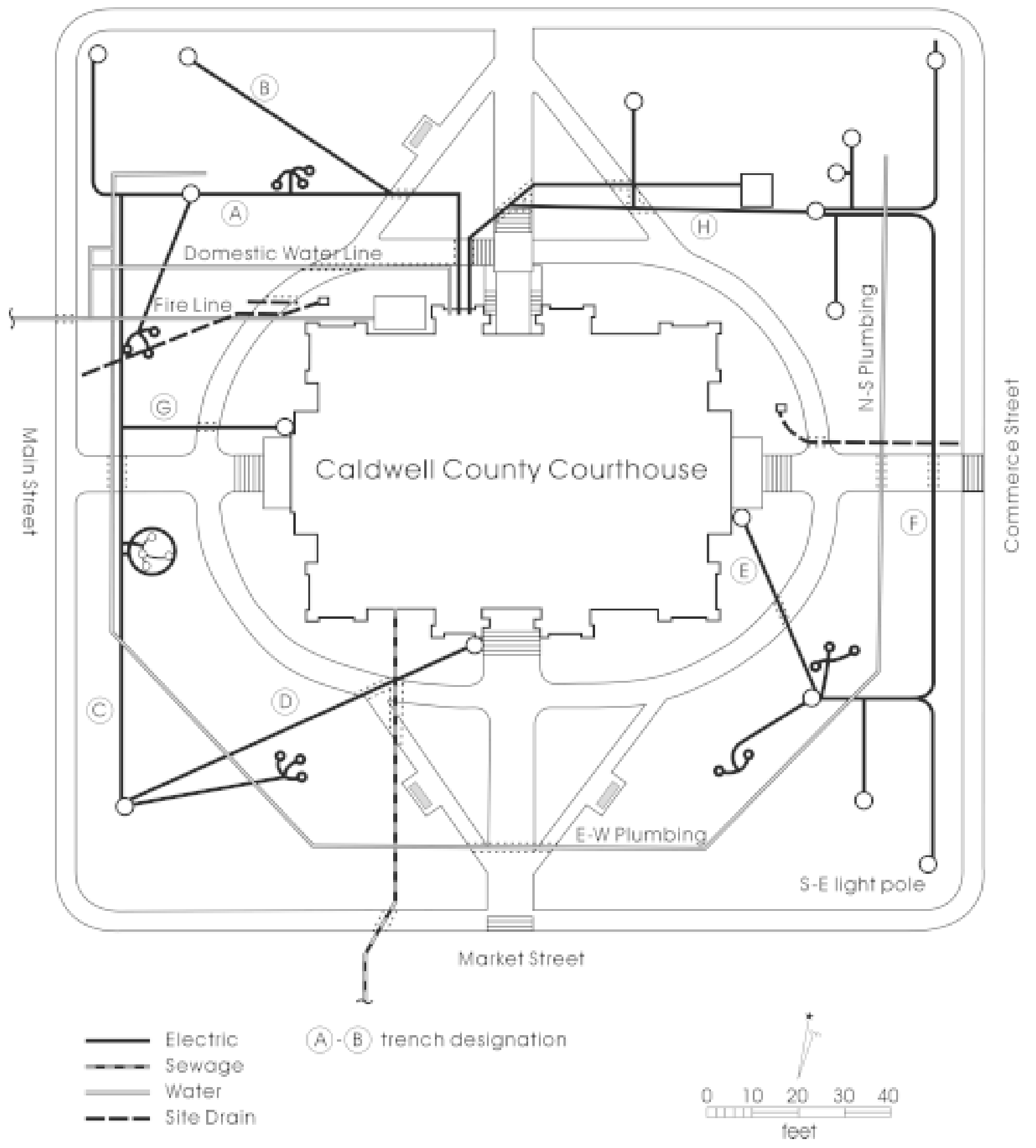

Figure 4. Map of trenching associated with exterior rehabilitation of the courthouse. 
profiles, and the screening of approximately 15 gallons of matrix from freshly excavated backdirt piles. In addition, Mr. Robbins and Mr. Bertrand, were also consulted regarding any artifacts that may have been noted and/or collected since the previous site visit. All artifacts recovered during these efforts were returned to CAR laboratories for washing, cataloging and analysis. Rick Robinson washed and cataloged the collection and Anne A. Fox completed the artifact analysis. All artifacts, field notes, and photographs produced during the project are curated at the CAR facility.

Although no excavations were to occur without the presence of an on-site archaeologist from CAR, the excavation of a number of electric line trenches on the north, east, and west sides of the courthouse had begun by the time of the first visit to the project area. In addition, the elevator well, measuring approximately $10 \times 12 \times 8$ feet, had been dug through the floor of the main northwest room of the courthouse.

\section{Results of Monitoring}

In general, the stratigraphy noted along the south side of the courthouse within the water line trench and the light pedestal hole is one of six inches of sandy loam landscape dirt introduced for flower bedding, underlain by 10 inches of Houston black clay heavily mixed with caliche pebbles. Segments of old water and sewage pipes were noted 16 inches below surface sticking out of the wall of the trench at three places along its length. Underlying this disturbed zone was eight inches of pure caliche that may have either been previously brought in as road-base or most likely represents the underlying bedrock. This portion of the lot appears to have been heavily disturbed by landscaping, and plumbing line installations-in part associated with an earlier sprinkler system.

Although landscaping-related disturbances were not noted on the other sides of the courthouse lot, the profiles examined showed other substantial disturbances. In general, the stratigraphy noted along the northern, eastern, and western sides of the courthouse consisted of between 6-12 inches of relatively recent dark brown clay loam introduced as fill. This fill is underlain by between 2-6 inches of disturbed matrix containing chunks of concrete (i.e., old sidewalk), gravel and/or caliche fill (Figure 5), electrical conduit, piping, and other modern materials. A lens of Houston black clay, ranging from 3-7 inches in thickness is found under this disturbed zone. Close examination of the profiles on each of the three sides of the courthouse revealed no artifacts in this zone.

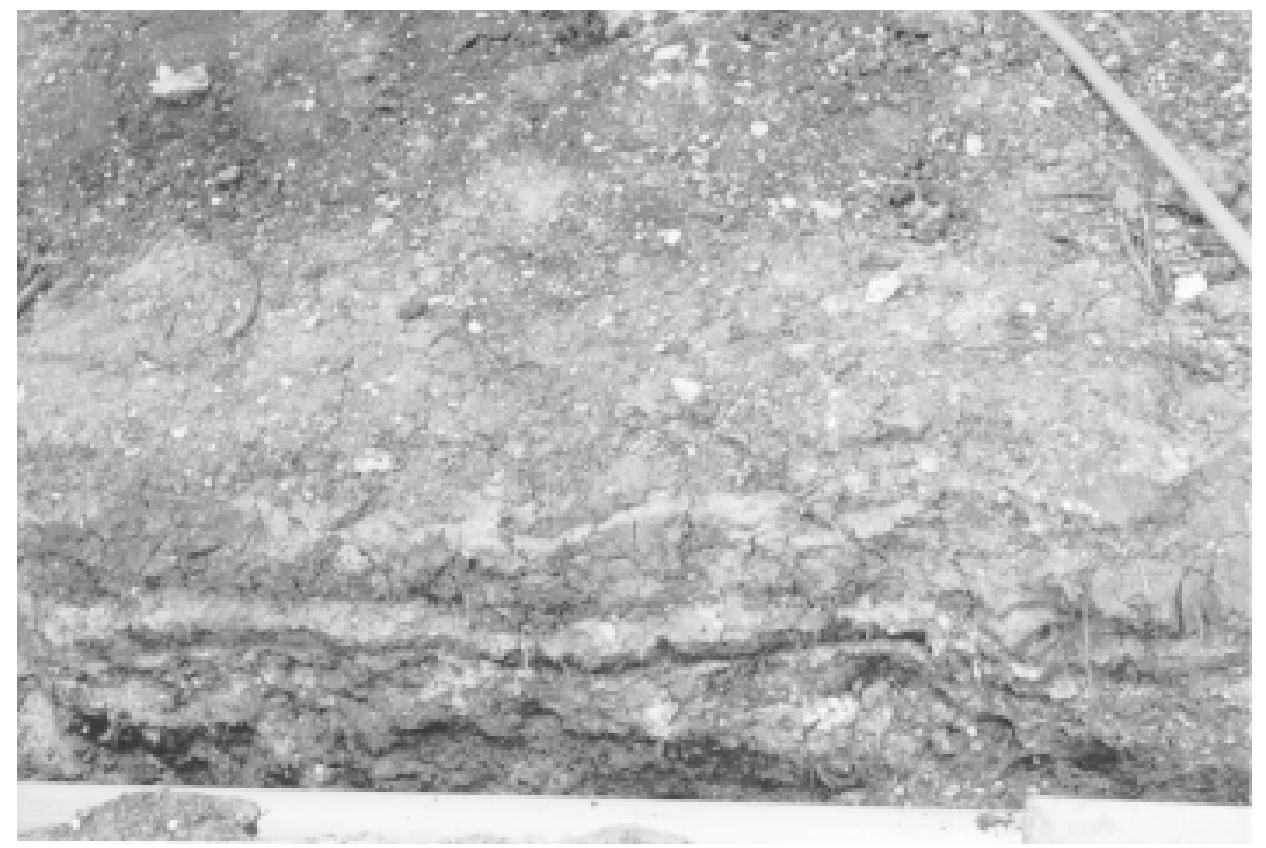

Figure 5. Superimposed construction layers and underlying disturbed zones in Trench F. 
This layer of clay sits on caliche bedrock around the entire perimeter of the lot. In some instances the apparently sterile clay zone on top of the caliche is itself dug through by the previous trenching associated with the installation of water lines (Figure 6).

\section{Artifacts Recovered}

A total of 412 artifacts was recovered during the course of the project either as part of the selective screening of the backdirt or as part of the surface collections (Table 1). Artifacts were not recovered from backdirt from several locations including; the sewage line, the site drain trenches, seven of the eight light pedestal holes, and the fire line trench. The bulk of the artifacts came from screening of the backdirt $(n=283$; $69 \%$ ). A total of 30 generalized artifact categories were identified in the collection. The two largest artifact categories consist of bottle glass and window glass. Moderate numbers of roofing slate fragments also were recovered with other artifact categories being represented by relatively small numbers. In general, artifacts representing the construction and use of the three successive courthouses are present in the collection. Detailed descriptions of the artifact categories, with specific attention given to temporal diagnostic artifacts, follow.

\section{Ceramics}

\section{Stoneware, Ink Bottles}

One bottle (three sherds) from the elevator pit has an impressed label,

\section{"VITREOUS STONE BOTTLES/ \\ J. BOURNE \& SON/ \\ PATENTEES/ \\ DENBY POTTERY/NEAR DERBY".}

A single sherd from Trench $\mathrm{C}$ is a basal fragment from an identical bottle but with a slightly lighter-colored glaze. Both bear a salt glaze over a brown slip. Bourne $\&$ Son established ca. 1850 was still in operation in 1976 (Herskovitz 1978:113). The ink contained in such bottles would probably have been used by employees at the first and second courthouses, and perhaps used during the earlier years of the present courthouse.

\section{Flower Pot}

One sherd from an unglazed earthenware flower pot came from Trench D. Identical pots, pressed into a mold and fired in a kiln, were advertised as early as 1895 (Montgomery Ward \& Co. 1969:537) and are still being made today. There does not seem to be anyway to date such sherds.

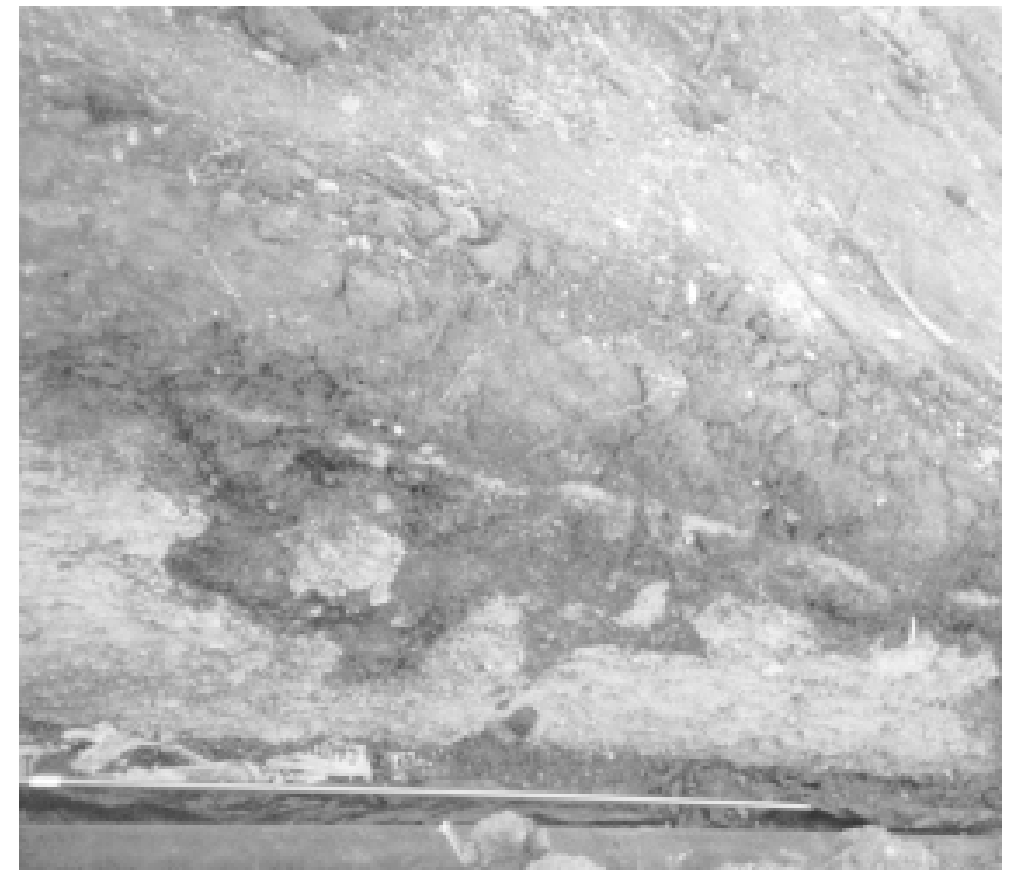

Figure 6. Close-up of fire line trench showing level of disturbance into underlying caliche. 
Table 1. Artifacts recovered from the monitoring of Caldwell County Courthouse rehabilitation activities

\begin{tabular}{|c|c|c|c|c|c|c|c|c|c|c|c|c|c|c|c|c|c|c|c|c|c|c|c|c|c|c|c|c|c|c|c|}
\hline & 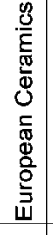 & 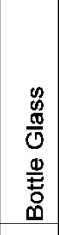 & 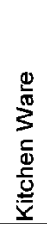 & $\begin{array}{l}0 \\
0 \\
\frac{0}{0} \\
0 \\
3 \\
0 \\
0 \\
0 \\
5 \\
3\end{array}$ & 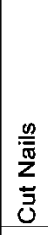 & 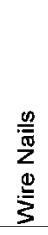 & $\begin{array}{l}0 \\
\stackrel{0}{0} \\
\stackrel{2}{0} \\
\dot{0}\end{array}$ & 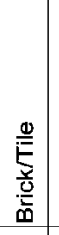 & 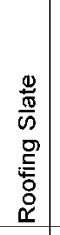 & 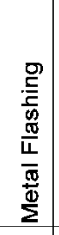 & 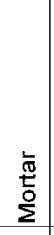 & $\begin{array}{c} \pm \\
\stackrel{5}{0} \\
\dot{\omega}\end{array}$ & $\frac{\grave{2}}{2}$ & 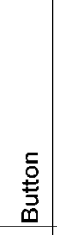 & 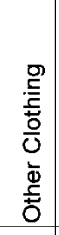 & $\begin{array}{l}5 \\
\overline{\bar{O}} \\
\end{array}$ & 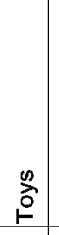 & 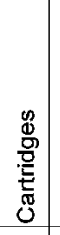 & 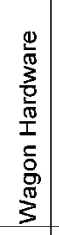 & 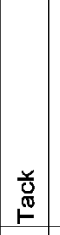 & $\begin{array}{l} \pm \\
\stackrel{5}{0} \\
\overline{0} \\
\frac{\mathbb{J}}{\bar{\Sigma}} \\
\mathbf{\Sigma}\end{array}$ & 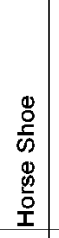 & $\begin{array}{l}\frac{\infty}{8} \\
\stackrel{\circ}{\circ}\end{array}$ & 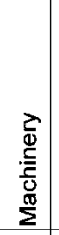 & 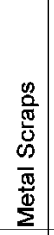 & 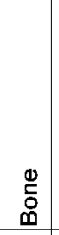 & $\begin{array}{l}\overline{\mathrm{g}} \\
\mathrm{\delta}\end{array}$ & $\begin{array}{l}\frac{t}{0} \\
\frac{0}{0}\end{array}$ & 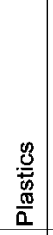 & 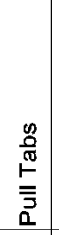 & $\begin{array}{l}\frac{\infty}{0} \\
\frac{\pi}{0} \\
\end{array}$ \\
\hline \multicolumn{32}{|l|}{ Screened Back Dirt } \\
\hline Trench A & & & & 4 & & 1 & & & & & & & & & & & & & & & & & & & & & & & 1 & & 6 \\
\hline Trench B & & & & 1 & & 2 & & & & & & & & & & & & & & & & & & 1 & & & & & & & 4 \\
\hline Trench C & 1 & 5 & & & & & & & & & & & & & & & & & & & & & & & & & & & & & 6 \\
\hline Trench D & 1 & 10 & 1 & 9 & & & & & & & & & & & & & & & & & & & & & & & & & & & 21 \\
\hline Trench E & & 3 & & 8 & & & & & & & & & 3 & & & & & & & & & & & & & & & & 3 & & 17 \\
\hline Trench F & & 3 & & 2 & & & & & & & & & & & & 1 & 1 & & & & & & & & & & & & & & 7 \\
\hline Trench G & & 4 & & & 1 & 5 & & 1 & & & & & & & & & & & & & & & & & & & & & 1 & 2 & 14 \\
\hline Trench H & & 2 & & 5 & 1 & & & & & & & & & & 1 & & & & & & & & & & 2 & & & & & & 11 \\
\hline E-W Plumbing & 1 & 10 & & 8 & 2 & 3 & & 1 & 24 & 1 & & & & & & & & 1 & & & & & & & & & 7 & 1 & 1 & & 60 \\
\hline N-S Plumbing & & 13 & & 11 & & 2 & & & 21 & & 1 & & & & & & & & & & & & & & 1 & & & & & & 49 \\
\hline Domestic Water Line & & 26 & & 6 & & 2 & & & 8 & & 5 & & 2 & 1 & & & & & & & & & & & 6 & & 8 & 1 & 1 & & 66 \\
\hline SE light pole & & 2 & & 3 & & & & & 6 & & & 3 & & & & & & & & & & & & & & 1 & & & & & 15 \\
\hline Elevator $\mathrm{Pit}^{\star}$ & 3 & & & & 2 & & & 2 & & & & & & & & & & & & & & & & & & & & & & & 7 \\
\hline Back Dirt Totals & 6 & 78 & 1 & 57 & 6 & 15 & 0 & 4 & 59 & 1 & 6 & 3 & 5 & 1 & 1 & 1 & 1 & 1 & 0 & 0 & 0 & 0 & 0 & 1 & 9 & 1 & 15 & 2 & 7 & 2 & 283 \\
\hline \multicolumn{32}{|l|}{ Surface Collections } \\
\hline East Entry & & 2 & 1 & & & & & & & & & & & & & & & & 2 & 1 & 1 & 1 & & & 1 & & & & & & 9 \\
\hline NE Corner & & 21 & & 21 & & & & & & & & & & & & & & & & & & & 1 & & 1 & & & & & & 44 \\
\hline NW Corner & & 8 & & 4 & 2 & 2 & & & 4 & & & & & & & & 1 & 1 & & & & & & & & & 1 & & & & 23 \\
\hline SW Corner & 3 & 5 & & & 1 & 1 & 1 & 1 & & & & & 2 & & & & & & & & & & & & & 2 & & & & & 16 \\
\hline SE Corner & 2 & 9 & & 26 & & & & & & & & & & & & & & & & & & & & & & & & & & & 37 \\
\hline Surface Collections Totals & 5 & 45 & 1 & 51 & 3 & 3 & 1. & 1 & 4 & 0 & 0 & 0 & 2 & 0 & 0 & 0 & 1 & 1 & 2 & 1 & 1 & 1 & 1 & 0 & 2 & 2 & 1 & 0 & 0 & 0 & 129 \\
\hline & & & & & & & & & & & & & & & & & & & & & & & & & & & & & & & \\
\hline Grand Totals & 11 & 123 & 2 & 108 & 9 & 18 & 1 & 5 & 63 & 1 & 6 & 3 & 7 & 1 & 1 & 1 & 2 & 2 & 2 & 1 & 1 & 1 & 1 & 1 & 11 & 3 & 16 & 2 & 7 & 2 & 412 \\
\hline * artifacts removed from pit & & & & & & & & & & & & & & & & & & & & & & & & & & & & & & & \\
\hline
\end{tabular}




\section{White Earthenware}

White-bodied earthenwares were being imported to Texas from England during the first half of the $19^{\text {th }}$ century. Six undecorated sherds of this type were recovered from various locations. These could be fragments of otherwise decorated vessels or could represent the last half of the century when the fashion changed to totally undecorated wares. It is difficult to say how these obviously residential-type artifacts arrived on the courthouse lawn.

\section{Bottle Glass}

Sherds of bottle glass (123) were recovered from nearly every unit. Most colors of glass used in the $19^{\text {th }}$ and first half of the $20^{\text {th }}$ century were present - clear, aqua, olive green, bright green, blue, and brown. What few fragments were large enough to be identified came from clear medicine bottles made primarily after the invention of the automatic bottle-making machine in 1903 (Lorrain 1968:43).

One larger fragment of blue green glass which was found in the northwest corner of the site represents an insulator. This type was used on light poles in the late $19^{\text {th }}$ century.

\section{Kitchenware}

A heavy iron handle from a wash boiler or large metal tub came from the surface adjacent the east entry area. Its construction design and method of attachment to its vessel suggest that this item dates to the late $19^{\text {th }}$ century.

A fragment of a white glass canning-jar lid liner was found in Trench D. The "opal glass lid liner" was invented in 1869 (Munsey 1970:146), and this would tend to associate the object within the time-frame of the second or present courthouse.

\section{Construction Materials}

\section{Window Glass}

Of the 108 fragments of window glass recovered, 51 measured $1 \mathrm{~mm}$ (1/16 in) in thickness, while 57 mea- sured $3 \mathrm{~mm}$ (1/8 in). It has been reported (Moir 1988:269) that window glass thickness gradually increased throughout the $19^{\text {th }}$ century. Therefore, it seems likely that the $1 \mathrm{~mm}$ glass represents the earlier courthouses, while the $3 \mathrm{~mm}$ glass is either from construction or from later repairs to the present courthouse.

\section{Cut Nails}

Cut or square nails were in use throughout the $19^{\text {th }}$ century in Texas. They were not popularly in use after the $1880 \mathrm{~s}$. The nine cut nails found in various locations on the courthouse grounds would have been used in the construction of the first two courthouses, but probably not in the present one.

\section{Wire Nails}

Wire nails were coming into use (Nelson 1968:10) about the time of the construction of the present courthouse. Therefore, the 18 wire nails recovered from various trenches probably were left during construction or later repairs to the present building.

\section{Spike}

A portion of a heavy iron spike was recovered during surface collection adjacent the southwest corner of the building. The shaft of the spike was $1 / 2$-in square.

\section{Brick/Tile}

Three tan colored brick fragments were recovered, one each from Trench G, the east-west plumbing trench, and the southwest corner surface collection. We are unable to speculate where they might have been used.

Two red tiles 2 -in $\times 6$-in $\times 1 / 2$-in came from the elevator pit. One bears the mark, "U.S.E.T."

\section{Roofing Slate}

Small fragments of black roofing slate (63 in all) were found in various locations on the site. These are probably from the roof of the present courthouse, perhaps the result of hail storms or other weathering.

One triangular fragment of metal flashing came from the east-west plumbing trench. Since the metal is still in good condition, it may be the result of recent roof repairs on the present courthouse. 
One fragment of cement mortar was recovered from the north-south plumbing trench. This type of mortar was in use at the time of the construction of the present courthouse.

Five fragments of sand and lime mortar came from the domestic water line trench on the northwest side of the site. Lime mortar would probably have been in use at the time of the construction of the first two courthouses.

Three small fragments of red sandstone came from the surface adjacent the southeast corner of the building. These are probably cast-offs from shaping the Red Pecos sandstone used in building the present courthouse (Kelsey and Dyal 1993:58).

\section{Pipe}

Seven pieces of iron pipe of various diameters were recovered during trenching and from surface collection on the courthouse square.

\section{Personal Items}

\section{Button}

A small (5/16-in) cut-shell button came from the domestic water line trench on the northwest side of the square. Such small buttons were customarily used on baby clothes in the late $19^{\text {th }}$ century. Cut-shell buttons were made after 1850 (Albert and Kent 1949:59).

\section{Safety Pin}

A broken nickel-plated safety pin, ca. 2-in long, came from Trench H. Similar pins are illustrated for sale in catalogs of the late $19^{\text {th }}$ century (Montgomery Ward and Co. 1969:87; Israel 1993:322).

\section{Coin}

A 1900 Liberty Head nickel was recovered from Trench F. It shows considerable wear and it is speculated that it was probably carried around in someone's pocket for several years before being lost on the courthouse lawn.

\section{Marble}

Trench F also yielded a 1950s glass marble (identified by José Zapata, CAR).

\section{Doll}

A porcelain doll's leg came from the northwest corner of the square. The doll would have had a body of soft material and porcelain head, arms, and legs. Judging by the size of the leg, this would have been a large and fairly expensive doll that dated between the 1890s and 1910 (Meissner 1997:61).

\section{Cartridges}

A .22 caliber short cartridge came from the east-west plumbing trench. This has been and continues to be a very popular cartridge.

Surface collection from the northwest corner yielded an externally primed .45 caliber cartridge. Marked "USC CO./ 45 COLT", this type was used from the 1880 s to the early 1900s (Sam Nesmith, personal communication 2000).

\section{Wagon or Carriage Hardware}

From a surface collection conducted at the east entry of the courthouse came two heavy pointed objects, each with a circular loop at one end. One is six inches long, the other 4 inches. They have been tentatively identified as hardware, related to wagons or carriages, due to their proximity to the horse-related artifacts described below.

\section{Tack}

\section{Horse Tack}

A bit described in the 1897 Sears, Roebuck catalog as a driving bit, stiff mouth type (Israel 1993:760), came from a surface collection adjacent the east entrance to the courthouse.

\section{Horse and Mule Shoes}

The same area noted above yielded a horseshoe and a mule shoe with heel caulks. 


\section{Tools}

The only tool recovered is a pair of modern grass shears, probably overlooked by someone working on the courthouse grounds.

\section{Machinery}

A large, hand-forged iron piece from Trench B closely resembles a plow point illustrated by Simmons and Turley in their book on Spanish ironwork (1980:83). They identified it as a New Mexico plow point, which would have been attached to a wooden plow. How such an object arrived at this location is unknown.

\section{Miscellaneous}

\section{Metal Scrap}

Eleven fragments of unidentifiable rusted metal scrap were recovered from various locations.

\section{Bone}

Three small bone fragments were found in trenches near the southeast and southwest corners. These items are not large enough to be identifiable.

\section{Coal}

The 16 fragments of coal recovered from various trenches probably represent the fuel used for stoves that heated the courthouses at different times.

\section{Chert}

Two broken fragments of chert recovered do not appear to have been altered unless by heavy machinery. These items do not indicate signs of intentional workmanship.

\section{Plastic}

A number of small plastic caps or stoppers for contemporary containers, one red washer-like object through which is thrust a short wire nail, and three fragments of black plastic pipe all can be considered recently made objects that do not directly relate to the courthouses.

\section{Pull tabs}

Two aluminum pull tabs from contemporary soft drink cans are also not related.

\section{Summary and Recommendations}

In February 1999 CAR- UTSA entered into a contract with American Restoration of New Braunfels, Texas, to monitor utility trenches being excavated on the grounds of the Caldwell County Courthouse in Lockhart, Texas. The utilities were installed in connection with the exterior rehabilitation being conducted by the firm of Ford, Powell, and Carson, Architects. The goal of the monitoring was to assure that trenching activities impacted no intact cultural deposits, such as features and foundations.

Five visits to the project between February and October of 1999 involved monitoring of mechanical trench excavations, selective screening of trenching backdirt, and surface collections. A total of eight trenches dug to receive electric lines were monitored (Trenches A$H)$. In addition, the excavation of eight light pedestal holes was also monitored on the four corners of the courthouse property. Two additional trenches, associated with the installation of water lines were also monitored. Also, the excavation and installation of the fire line adjacent the northwest corner of the courthouse, running to Main Street was monitored. In addition to these efforts, surface collections of artifacts were made at several locations including adjacent the east entryway, and between the building and the sidewalk adjacent the four corners of the building.

Based on the examination of the stratigraphy and contents of the various trenches along the south side of the courthouse, this portion of the lot appears to have been heavily disturbed by landscaping and the installation of earlier sprinkler systems. The trench profiles examined along the northern, eastern, and western sides of the courthouse lot showed other substantial disturbances related to previous construction activities, such as, the installation of sewer and electric lines, and sidewalk construction. No traces of the foundations of the two previous courthouses were encountered during the trenching and subsequent inspections. 
The selective screening of backdirt from the various trenches and surface collections revealed artifacts relating to the construction and use of the three successive courthouses that have existed on the site. However, these artifacts derive from heavily disturbed contexts containing a mix of late $19^{\text {th }}$ century to modern artifacts. It is our assessment that no significant intact cultural deposits were disturbed by the trenching and construction activities conducted by American Restoration of New Braunfels, in conjunction with the exterior rehabilitation of the Caldwell County Courthouse in Lockhart, Texas.

We commend American Restoration and Ford, Powell, and Carson, Architects, for the care they have shown in carrying out the restoration and rehabilitation work at this site, and the beautiful legacy they have recreated in the Caldwell County Courthouse building (Figure 7).

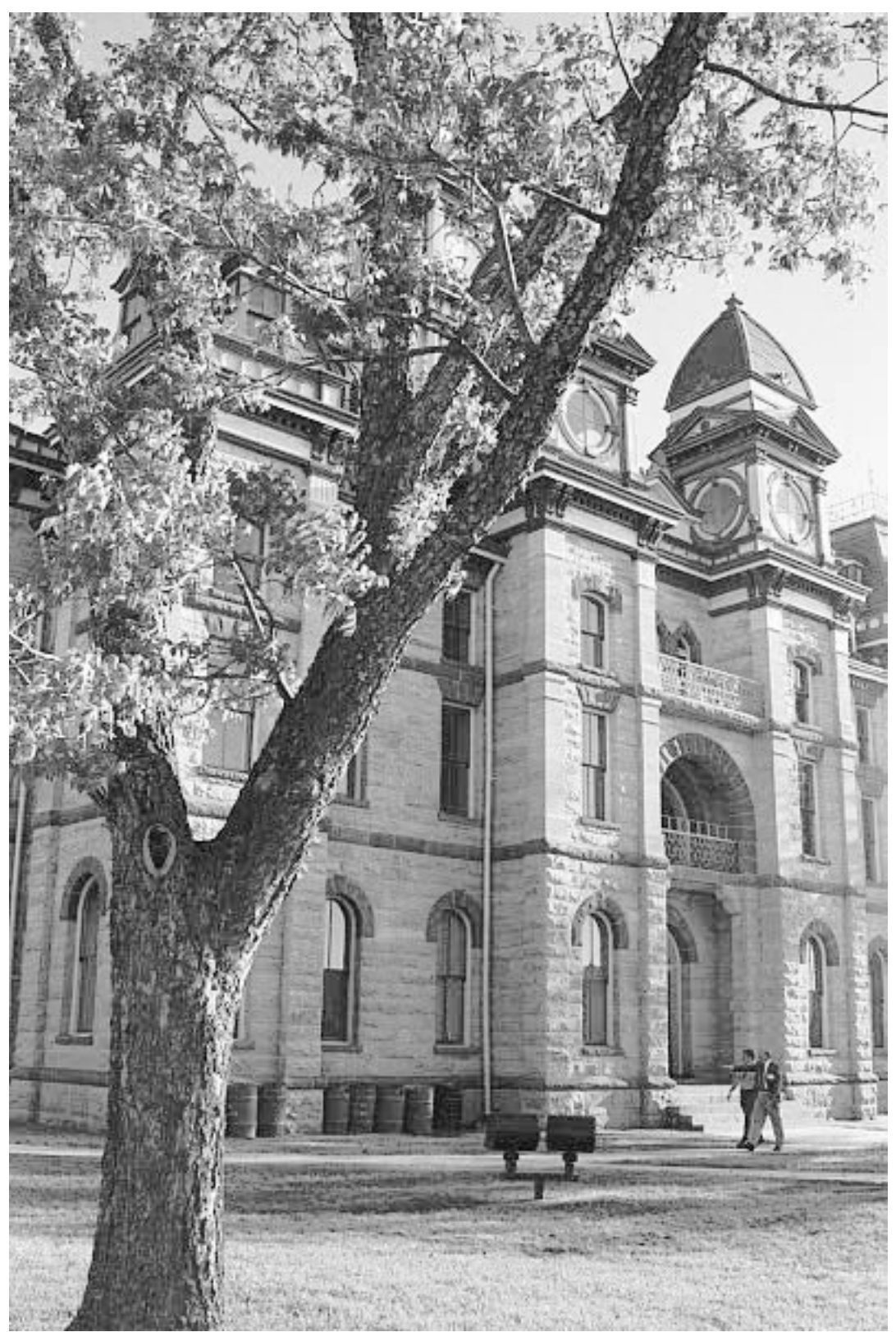

Figure 7. Caldwell County Courthouse on Courthouse Dedication Day, April 2000.

(Used with permission, Mike Annas, Annas Photography, Lockhart, Texas). 


\section{References Cited}

Albert, L. S., and K. Kent

1949 The Complete Button Book. John Edwards, Stratford, Connecticut.

Brice, D. E.

1986 The Caldwell County Courthouse. Plum Creek Almanac 4(1).

Herskovitz, R. M.

1978 Fort Bowie, Material Culture. The University of Arizona Press.

Israel, F. L., editor

19931897 Sears, Roebuck Catalog. First published in 1968, reissued by Chelsea House Publishers. New York.

Kelsey, M. P., Sr., and D. H. Dyal

1993 The Courthouses of Texas. Texas A\&M University Press. College Station.

Lorrain, D.

1968 An Archaeologist's Guide to Nineteenth Century American Glass. Historical Archaeology 2:35-44.

Meissner, B. A.

1997 Dolls, Toys, Games, and Other Diversions. In Archaeology at the Alamodome: Investigations of a San Antonio Neighborhood in Transition edited by Anne A. Fox, Marcie Renner, and Robert J. Hard. Vol. III, Artifact and Special Studies. Archaeological Survey Report No. 238, pp: 57-99. Center for Archaeological Research, The University of Texas at San Antonio.

Moir, R. W.

1988 Windows and Window Glass. In Historic Farming on the Hogwallow Prairies, Ethnoarchaeological Investigations of the Mountain Creek Area, North Central Texas, Volume II, compiled by D. H. Jurney, S. A. Lebo, and M. M. Green, pp. 263-272. Archaeology Research Program, Institute for the Study of Earth and Man, Southern Methodist University, Dallas.

Montgomery Ward \& Co.

1969 Montgomery Ward \& Co. Catalogue and Buyers 'Guide No. 57, Spring and Summer, 1895. Reprinted by Dover Publications, Inc., New York.

Munsey, C.

1970 The Illustrated Guide to Collecting Bottles. Hawthorn Books, Inc., New York.

Nelson, L. H.

1968 Nail Chronology As An Aid to Dating Old Buildings. American Association for State and Local History Technical Leaflet 48. 
Simmons, M., and F. Turley

1980 Southwestern Colonial Ironwork. Museum of New Mexico Press, Santa Fe.

Volz and Associates

1992 Caldwell County Courthouse, Preservation Master Plan. Prepared by Volz and Associates, Austin. 